\title{
Hòa hợp các giá trị truyền thống và ngoại quốc trong giáo dục và đào tạo nghề tại Việt Nam
}

\author{
Hồ Mạnh Toàn \\ SSHPA System \\ Nguyễn Minh Hoàng \\ Ritsumeikan Asia Pacific Unviersity, Beppu, Japan
}

Hà Nội, 8-11-2018

Hiện nay, Việt Nam hướng tới hội nhập, hiện đại hóa, và công nghiệp hóa trong các vấn đề bao gồm kinh tế, văn hóa, xã hội, giáo dục, nghiên cứu, và công nghệ. Trong đó việc giáo dục và đào tạo nghề được xem như yếu tố then chốt để phát triển nguồn lao động bền vững. Vì vậy, việc chắt lọc, điều chỉnh sao cho thích hợp với các cách tiếp cận và thực hành từ nước ngoài là rất cần thiết cho quá trình phát triển của giáo dục và đào tạo nghề.

Mới đây, hai tác giả Hồ Thị Hạnh Tiên (Trường Cao đẳng Công Nghiệp Huế) và Trần Thị Lý (Deakin University, Úc) đã công bố nghiên cứu Appropriation of foreign approaches for sustainable development and transformational changes in Vietnamese vocational education trên tạp chí Higher Education, Skills and Work-Based Learning (ESCl, CiteScore 1.01) [1]. Nghiên cứu đã chỉ ra được những thiếu sót và gợi ý các chính sách phù hợp với giáo dục và đào tạo nghề tại Việt Nam.

Bài nghiên cứu là một phần của một dự án nghiên cứu sử dụng phương pháp phân tích tài liệu, quan sát, và phỏng vấn bán cấu trúc với 22 người bao gồm người học nghề và nhân viện tại 3 địa điểm dạy nghề khác nhau. Trong công bố này, chỉ có 8 người được phỏng vấn và quan sát tại một trường cao đẳng nghề do Đức tài trợ và chịu sự quản lý của Bộ Lao động, Thương Binh và Xã Hội.

Kết quả phân tích cho thấy Việt Nam cần phải có một hệ thống sư phạm đào tạo nghề mới nhằm chắt lọc các ảnh hưởng từ nước ngoài, kết hợp chúng một cách linh hoạt, sáng tạo với các phương pháp sư phạm địa phương hiện có. Ngoài ra, hệ thống sư phạm mới cần phải phù hợp với cả lịch sử và tình hình chính trị của Việt Nam. Hệ thống đấy phải phù hợp với nền kinh tế thị trường định hướng xã hội chủ nghĩa và có khả năng tận dụng ảnh hưởng ngoại quốc như Khổng giáo, Pháp, Liên Xô và phương Tây. Sự cân bằng này đảm bảo Việt Nam sử dụng lực lượng từ quốc tế và cả thế mạnh địa phương để phát triển và thay đổi bền vững hơn là phụ thuộc thụ động vào các phương pháp được thực hành ở nước ngoài.

Thực tế mà nói, các ảnh hưởng ngoại quốc như Khổng giáo, Pháp, Liên Xô hay phương Tây đều đã ăn sâu vào đời sống và văn hóa của người Việt Nam, đặc biệt là các yếu tố Khổng giáo do sự ảnh hưởng của Trung Quốc trong suốt chiều dài lịch sử Việt Nam. Các giá trị truyền thống của Khổng giáo vẫn hằn sâu trong đời sống và suy nghĩ của người Việt như quan niệm 'sĩ-nông-công-thương' hay các mối quan hệ xã hội và cách ứng xử đi kèm với nó [2]. Tuy nhiên, sự phát triển của môi trường kinh tế cũng như sự thúc đẩy quá trình hội 
nhập trong những năm gần đây đang mang đến sự thay đổi mạnh mẽ, buộc các giá trị cũ phải cải biến trong môi trường mới.

Sự thay đổi và cải biến của các giá trị truyền thống khi tiếp xúc với các điều kiện mới từ lâu đã là một đặc tính của văn hóa Việt Nam [3]. Các giá trị khác nhau, đôi lúc còn trái ngược đôi khi lại được người Việt Nam dung hòa và cộng lại. Điển hình có thể kể đến sự đặc biệt của Hà Nội với sự pha trộn giữa kiến trúc Pháp, các ngồi nhà cổ kiểu Tàu và bây giờ là các tòa nhà cao tầng hiện đại. Thực tế, văn hóa cộng tính đó có thể mang lại nhiều vấn đề như trong giáo dục và kinh tế [3] hay hội họa [4], nhưng không thể phủ nhận, với sự kiểm soát ổn định, sẽ là một tiền đề để mang đến sự cân bằng cần thiết mà hai tác giả nghiên cứu đã đề cập.

*Phát triển từ bài giới thiệu nghiên cứu trên SSHPA: https://sc.sshpa.com/post/4334

\section{References:}

[1] Tien, T.H.H. \& Ly, T.T. (2018). Appropriation of foreign approaches for sustainable development and transformational changes in Vietnamese vocational education. Higher Education, Skills and Work-Based Learning, 8(4), 527-543, DOI: 10.1108/HESWBL-04-2018-0053.

[2] Vuong Q.H., Tran T.D. (2009). The cultural dimensions of the Vietnamese private entrepreneurship. The IUP Journal of Entrepreneurship Development, VI(3-4): 54-78.

[3] Vuong Q.H., La V.P., Vuong T.T., Nguyen V.H., Ho M.T., Nguyen T.H.K., Bui Q.K., Ho M.T. (2018). Cultural additivity: Behavioural insights from the interaction of Confucianism, Buddhism, and Taoism in folktales. Palgrave Communications, 4, DOI: 10.1057/s41599-018-0189-2. URL: https://www.nature.com/articles/s41599-0180189-2.

[4] Vuong, Q.H., Ho, M.T., Vuong, T.T., Tran, K., \& Ho, M. (2018b). “Paintings can be forged, but not feeling": Vietnamese art-Market, fraud, and value. Arts, 7(4), 62. 